\title{
The Determinants of Thailand's Road Vehicle Exports
}

\author{
Pimjai Promsuwan ${ }^{1}$, Soo Y. Chua ${ }^{2}$, \\ \{pimjai.pr@skru.ac.th ${ }^{1}$, sychua@usm.my² \\ Faculty of Management Sciences Songkhla Rajabhat University, Thailand ${ }^{1}$ \\ School of Social Sciences, Universiti Sains Malaysia ${ }^{2}$
}

\begin{abstract}
Road vehicles, which are a major manufacturing export, can increase employment and income for the Thai population. It has therefore necessitated the effective integration of information and communication technologies to enhance the comparative advantage in international markets. The research aims to investigate the factors affecting Thailand's road vehicle exports. The four factors (foreign direct investment, exchange rate, openness, and GDP per capita) were analyzed in the period 1980 to 2018 . The findings from the cointegration test shown that all four factors were positively related to road vehicle exports. The impulse response functions present that the real exchange rate was essential for road vehicle exports to grow from the third year onwards. A variance decomposition analysis revealed that GDP per capita and real exchange rate were an important factor of the ten-year forecast for road vehicle exports, followed by trade openness and foreign direct investment. Based on empirical research, the growth rate of GDP per capita can help to expand production capacity and to expedite exports. The depreciation of the Thai baht attracts more foreign investment and demand for Thai products. The growth in trade openness and foreign direct investment is also linked to increased export volume in this sector. Therefore, to promote sustainable growth in vehicle sales, the government needs to expand market destinations and entice foreign investors by offering more incentives.
\end{abstract}

Keywords: Thailand, Determinants, Road Vehicle Export

\section{Introduction}

It is clear that international trade has become increasingly important over the years whereby export-led growth strategies have played a vital role in generating economic development. Having a comparative advantage creates a gain from trade since it can boost investment, productivity, job opportunities and increases incomes.

Furthermore, a comparative advantage enhances economic growth and permits a movement of products, labor, investment, and information technology between countries. With export-oriented policy, each country has been 
attempting to produce and export to international markets. In so doing, the country's gross domestic product will increase consistently.

Thailand, as a truly global economy, is shifting from agro-based to technology-based industries. To maintain the standard of living, Thailand needs to compete in an ever-tougher global market. Through the adoption of a successful outward-oriented strategy, Thailand's exports are currently very dependent on manufacturing products and have increased continuously since 1980. Therefore, manufacturing products are important for Thailand's export sector.

Nowadays, Thailand depends greatly on the international market, where the economic factors, for instance foreign direct investment (FDI), gross domestic product per capita (GDP per capita), real exchange rate, and trade openness (the ratio of trade to GDP) play important roles. Periodically, there have been insufficient flows of FDI to Thailand, which negatively affects the export of manufacturing products. Moreover, Thailand has faced uncertain economic conditions that caused a reduction in the export of products. It is widelyrecognized that foreign investors need incentives and profits from long-term investment, but information on the determinants of the export of products remains limited. For this reason, more research studies are needed to inform policy and to understand the determinants of Thailand's exports in order to increase the rate of economic development.

The automobile industry in Thailand has been regarded as an important part of the Thai economy by successive governments. In the beginning, the focus was on import substitution. Later, the government changed to strategy to enhance the strength of the automotive sector, particularly through measures to improve the domestic production of vehicle parts. As a result, investment in the automotive parts sector has grown continuously and has strengthened the supply chain of the whole automotive sector. The production of the automotive sector rose from 0.36 million vehicles in 1997 to 1.99 million vehicles in 2018 . Moreover, this sector has focused on the export market since 2008 [15]. Interestingly, the export value for road vehicles increased from 16,390 million US\$ in 2008 to 27,000 million US\$ in 2018 [13], which is the largest export value of Thailand's total exports [9]. 


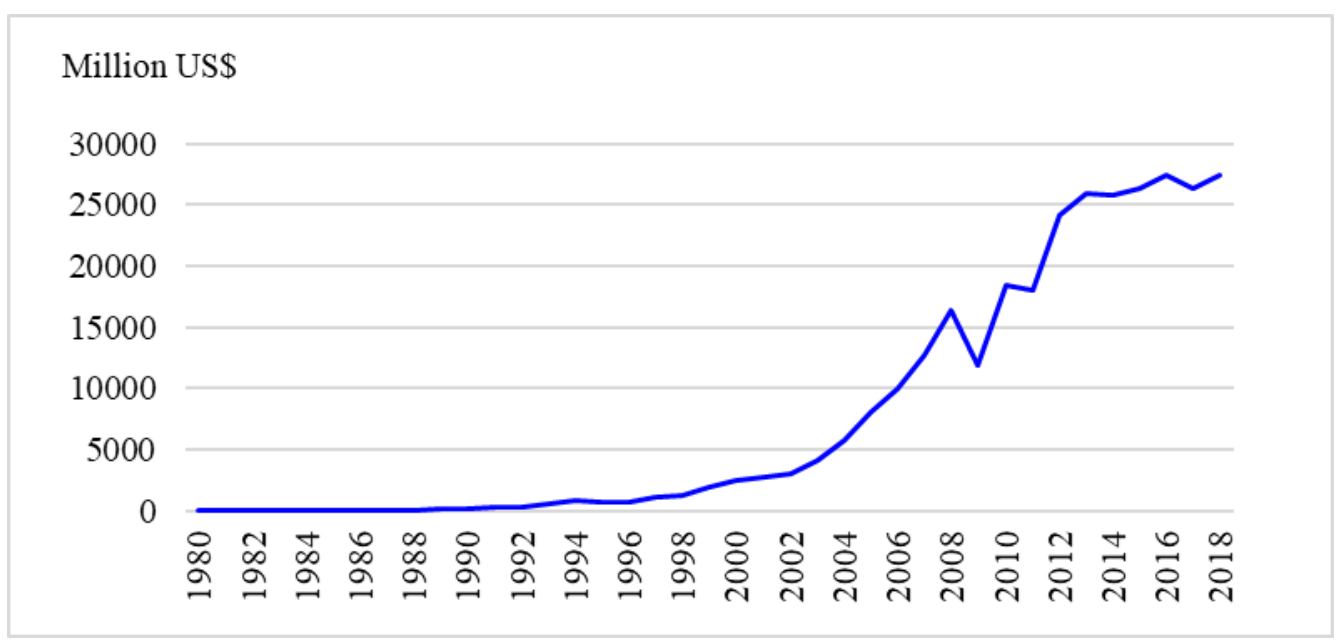

Figure 1. Thailand Road Vehicle Exports 1980-2018

Figure 1 shows that Thailand's road vehicle exports had a small value in the international market during 1980-2000, but the export value has gradually increased since 2000 and it noticeably increased from 2010 onwards due to government support.

Because road vehicles have become an important export of Thailand, this study aims to investigate the determinants of Thailand's road vehicle exports. The results of this study will provide up-to-date insights into the motivations of investors and the implications for policymakers.

\section{Literature Review}

Regarding classical trade theories, if each country specialized in and exported their products, they would have a comparative advantage. Furthermore, businesses specialize and earn profits that derive from the economies of scale and product differentiation. However, export competitiveness between countries is more complicated as each country needs to evaluate their export performance, which may depend on other factors (i.e. exchange rate). Thus, many economists have examined the determinants of export performance. Liu and Shu [7] examined the determinants of Chinese exports. The results showed that FDI affected Chinese export performance. Vural and Zortuk [14], determined the factors affecting Turkey's exports. The results revealed that FDI was positively related to Turkey's export supply. 
Selimi et al. [12] examined the impact of FDI on the export performance in Western Balkan. The findings revealed that FDI had a positive effect on export performance. Bhatt [1], studied the effect of FDI on China's exports with the VAR approach. The cointegration test indicated the existence of a long-run relationship between exports, GDP, and FDI. In addition, the estimation of the error correction model showed that FDI had a positive relationship with China's exports. Using cointegration tests, Enimola [2], investigated the relationship between export growth and FDI in Nigeria through the period of 1970-2008. The results showed that the real effective exchange rate, GDP, and FDI were positively related to exports while trade openness was found to be irrelevant. Epaphra [3], employed Johansen's cointegration test to study the factors influencing the export of Tanzania during 1966 to 2015. The results revealed that the exchange rate, GDP per capita, and trade liberalization had a positive effect on export performance. Similarly, Mohsen [10], investigated the impact of oil prices, trade openness, and exchange rate on the Syria's exports for the period of 1970-2010. The results from the cointegration test revealed that trade openness and oil prices were positively related to Syrian exports, but the exchange rate showed a negative relationship. Although many researchers used similar economic factors and methods, the results were different depending on each country's data and time frame. Therefore, in this study, the proposed determinants of Thailand's road vehicle exports are foreign direct investment, real exchange rate, gross domestic product per capita, and trade openness.

\section{Methodology}

To identify the determinants affecting road vehicle exports, four factors were investigated. FDI inflow can support a country as a source of capital, production, information technology, and knowledge management systems. Alongside knowledge- based sources of technology, manufacturing exports could compete effectively in the global market. Consequently, FDI is likely to impact the country's exports. The growth of GDP per capita leads firms and industries to develop as well as encourage economic growth. GDP per capita is thus an indicator that can be used to examine the export achievement. If the Thai Baht depreciates, Thai export prices in other currencies will fall, which drives export demand. Thus, the real exchange rate is also a factor that contributes to exports. Lastly, trade openness can help a country to reduce trade limitations and can thus increase exports. 


\subsection{The Road Vehicle Export Model}

Based on the five-factors, road vehicle export (EXROAD) as the dependent variable. The four-independent variables including foreign direct investment (FDI), gross domestic products per capita (PERC), real exchange rate (REX) and trade openness $(\mathrm{OPN})$.

The road vehicle export model is as follows:

$$
\operatorname{lnEXROAD}=\beta_{0}+\beta_{1} \operatorname{lnFDI}+\beta_{4} \ln \mathrm{PERC}+\beta_{2} \operatorname{lnREX}+\beta_{3} \mathrm{OPN}+u_{i}
$$

In the export model, the variables; EXROAD, FDI, PERC, and REX are in the natural $\log$ form. In particular, $\beta_{0}$ is a constant, $\beta_{1}$ is a coefficient of $\operatorname{lnFDI}$, $\beta_{2}$ is a coefficient of $\operatorname{lnPERC}, \beta_{3}$ is a coefficient of $\operatorname{lnREX}, \beta_{4}$ is a coefficient of OPN, and $u_{i}$ is the error term.

\subsection{Data}

In this study, the annual time series data of Thailand during the period 19802018 was gathered from UNComtrade (2020), IMF (2020), and the World Bank (2020). The variables are shown in logarithmic form, except for OPN. Additionally, FDI is regarded as net inflows into Thailand (US dollar). GDP per capita (PERC) is Thailand's GDP divided by the population (US dollar). For the trade openness (OPN), it is the sum of Thailand's imports and exports, estimated as a percentage of GDP, Moreover, real exchange rate; REX (Baht per US dollar) is the nominal exchange rate (NER) adjusted by the relative price of goods of two countries (USA and Thailand). The computation of REX is as follows: $\mathrm{REX}=$ nominal exchange rate $\times\left(\mathrm{P}_{\mathrm{US}} / \mathrm{P}_{\mathrm{TH}}\right)$

\subsection{Estimation}

An econometric model was employed to investigate the determinants of road vehicle exports. The ADF (Augmented Dickey-Fuller) unit root is applied to test the stationarity of all variables. If all variables are stationary in the same order as first difference, the testing of cointegration can be continued. If the variables in the export model are cointegrated, the granger causality will be used. Furthermore, variance decomposition analysis (VD) and impulse response functions (IRF) will be employed to evaluate whether the independent variables are able to explain the variation of road vehicle export in the short and long run predicting. 


\section{Results}

This study purposes to estimate the determinants of Thailand's road vehicle exports. Various tests can be used to achieve this result.

\subsection{The ADF Unit Root Test}

Using the ADF unit root test, the results showed that all variables in the road vehicle export model are non-stationary at level, but all variables turn into stationary at the first difference. The results are confirmed below.

Table 1. ADF unit root test

\begin{tabular}{lllllll}
\hline & \multicolumn{3}{c}{ At Level } & \multicolumn{3}{c}{ At first difference } \\
\cline { 2 - 7 } & Intercept & $\begin{array}{c}\text { Trend \& } \\
\text { intercept }\end{array}$ & None & Intercept & $\begin{array}{l}\text { Trend \& } \\
\text { intercept }\end{array}$ & None \\
\hline lnEXROAD & -1.5131 & -0.1983 & 2.4541 & $4.2701 * * *$ & $-4.6964 * * *$ & $-2.9083 * * *$ \\
lnFDI & -1.5210 & -3.4138 & 1.3564 & $9.4116^{* * *}$ & $-9.3363^{* * *}$ & $-9.1594 * * *$ \\
lnPERC & -0.7878 & -2.5933 & 1.9314 & $3.7649 * * *$ & $-3.7126^{* *}$ & $-3.0391 * * *$ \\
lnREX & -2.1317 & -1.6289 & 0.6217 & $4.5285 * * *$ & $-4.6200^{* * *}$ & $-4.5697 * * *$ \\
OPN & -1.1504 & -1.2976 & 1.0844 & $6.5601 * * *$ & $-6.6123^{* * *}$ & $-6.2102^{* * *}$ \\
\hline
\end{tabular}

Note. $* * *$ significance level at .01, and ** significance level at .05

\subsection{The Cointegration Test}

After unit root test found that all variables are stationary at first difference, the cointegration test can be continued to determine the long-run relationships among the variables in the road vehicle export model. Prior proceed the cointegration test, it's necessary to run the VAR model first to verify the best lag length. Based on the minimum value of the Akaike information criterion (AIC), the optimal lag length for this study is two lags. The optimal lag length is presented below.

Table 2. Optimal Lag length

\begin{tabular}{cccllll}
\hline Lag & LogL & LR & FPE & AIC & SC & HQ \\
\hline 0 & -165.8432 & NA & 0.007051 & 9.234767 & 9.452458 & 9.311513 \\
1 & 1.978016 & 281.2139 & $3.17 \mathrm{e}-06$ & 1.514702 & $2.820851^{*}$ & 1.975181 \\
2 & 35.23574 & $46.74058^{*}$ & $2.20 \mathrm{e}-06^{*}$ & $1.068338^{*}$ & 3.462946 & $1.912550^{*}$ \\
\hline
\end{tabular}

* lag length selected by AIC criterion 
To continue the Johansen cointegration test, the lag length is set as two lags. Based on trace statistics and max- eigen statistical value, there are two cointegration equations in this model. Accordingly, there is a long-run relationship among the variables $\operatorname{lnEXROAD}$, $\operatorname{lnFDI}, \ln P E R C$, $\ln R E X$, and OPN.

Table 3. Johansen Cointegration Test

\begin{tabular}{clccccc}
\hline $\begin{array}{l}\text { No. of } \\
\text { cointegrating } \\
\text { equations }\end{array}$ & $\begin{array}{l}\text { Trace } \\
\text { Statistic }\end{array}$ & $\begin{array}{c}\text { Critical } \\
\text { Value } \\
0.05\end{array}$ & $\begin{array}{c}\text { Prob. } \\
0.05\end{array}$ & $\begin{array}{c}\text { Max-Eigen } \\
\text { Statistic }\end{array}$ & $\begin{array}{c}\text { Critical } \\
\text { Value } \\
0.05\end{array}$ & $\begin{array}{c}\text { Prob. } \\
0.05\end{array}$ \\
\hline $\mathrm{r}=0$ & $103.4733^{* *}$ & 76.97277 & 0.0001 & $39.33730^{* *}$ & 34.80587 & 0.0134 \\
$\mathrm{r} \leq 1$ & $64.13603^{* *}$ & 54.07904 & 0.0049 & $36.17416^{* *}$ & 28.58808 & 0.0044 \\
$\mathrm{r} \leq 2$ & 27.96186 & 35.19275 & 0.2430 & 14.04938 & 22.29962 & 0.4575 \\
$\mathrm{r} \leq 3$ & 13.91248 & 20.26184 & 0.2955 & 9.136465 & 15.89210 & 0.4193 \\
$\mathrm{r} \leq 4$ & 4.776018 & 9.164546 & 0.3089 & 4.776018 & 9.164546 & 0.3089 \\
\hline
\end{tabular}

Note. $* *$ significance level at .05

Therefore, the cointegration equation for road vehicle exports was normalized using $\operatorname{lnEXROAD}$ as a dependent variable. As a result, the normalized cointegrating equation is presented in Table 4.

Table 4. Normalized cointegrating equation

\begin{tabular}{crrrrc}
\hline $\ln E X R O A D$ & lnFDI & lnPERC & lnREX & OPN & C \\
\hline 1.000000 & -0.349444 & -2.311835 & -2.254957 & -0.017198 & 14.22470 \\
& $(0.04331)$ & $(0.08885)$ & $(0.22721)$ & $(0.00237)$ & $(1.15740)$ \\
\hline
\end{tabular}

From the normalized cointegrating equation, the long-run equation of $\operatorname{lnEXROAD}$ can be composed as follows:

$$
\begin{aligned}
\operatorname{lnEXROAD}=\quad & -14.22470+0.349444 \operatorname{lnFDI}+2.311835 \ln \mathrm{PERC} \\
+ & 2.254957 \ln \mathrm{REX}+0.017198 \mathrm{OPN}
\end{aligned}
$$

The equation shows that road vehicle exports (lnEXROAD) are positively related to $\operatorname{lnFDI}$, $\ln P E R C$, $\operatorname{lnREX}$, and OPN.

The coefficient of lnFDI indicates that for an increase in FDI of one percent, road vehicle exports will increase by 0.35 percent, which suggests that this sector earns benefits from FDI to improve high-standard products with a source of capital, the latest knowledge, and advanced technology. Thus, this sector can 
export high-quality products and the export volume can be increased. This result supports the findings of Liu and Shu [7], Zhang [16], Jongwanich [4], Vural and Zortuk [14], Enimola [2], Bhatt [1] and Selimi et al. [12]. The coefficient of $\ln$ PERC shows that if GDP per capita rises by one percent, road vehicle exports will rise by 2.31 percent. GDP per capita represents the well-being of the population based on GDP growth. With higher well-being, this sector will have the ability to develop the export of its products to international markets. This result is in line with Epaphra [3] and Kumari and Malhotra [6].

The coefficient of lnREX indicates that if the real exchange rate grows by one percent, road vehicle exports will grow by 2.25 percent. The depreciation of the Thai Baht results in decreasing export prices in foreign markets. Consequently, foreign demand for Thailand's exports is more likely to increase. The real exchange rate thus plays an important role in road vehicle exports. This result supports the findings of Majeed et al. [8] and Epaphra [3]. The coefficient of OPN explains that if openness increases by one percent, the road vehicle exports will grow by 0.02 percent. The Thai government is focusing on an outward-oriented strategy to achieve economic growth. Trade liberalization increases by seeking new markets for road vehicle exports. Therefore, Thailand can benefit from the extension of trade openness to improve exports. The result is in line with Hoque and Yusop, Z. [5], Mohsen [10], Epaphra [7], and Mohsen et al. [11] (2017). In conclusion, GDP per capita and real exchange rate both impact road vehicle exports.

Since the variables in the export model are cointegrated, it means that there is a long-run relationship among the variables. Then, the Vector Error Correction Model (VECM) can be used to estimate short-run adjustments to the long-run equilibriums. The error correction term is as follows:

$$
\begin{aligned}
\mathrm{ECT}_{\mathrm{t}-1}= & 1.000 \ln \mathrm{EXROAD}_{\mathrm{t}-1}-0.191 \operatorname{lnFDI}_{\mathrm{t}-1}-2.279 \ln \mathrm{PERC}_{\mathrm{t}-1} \\
& -1.748 \ln \operatorname{REX}_{\mathrm{t}-1}-0.027 \mathrm{OPN}_{\mathrm{t}-1}+9.681
\end{aligned}
$$

Short-run equation estimated from VECM

$$
\begin{aligned}
\Delta \ln E X R O A D_{\mathrm{t}}= & -0.040 \mathrm{ECT}_{\mathrm{t}-1}+0.542 \Delta \operatorname{lnEXROAD}_{\mathrm{t}-1}-0.036 \Delta \ln _{\mathrm{nDDI}} \mathrm{t}_{\mathrm{t}-1} \\
& -0.058 \Delta \operatorname{lnPERC}_{\mathrm{t}-1}+0.258 \Delta \operatorname{lnREX}_{\mathrm{t}-1}-0.009 \Delta \mathrm{OPN}_{\mathrm{t}-1}+0.123
\end{aligned}
$$

From the equation, the coefficient of the error correction term (ECT) held the correct sign. It means that the previous periods deviation from long-run equilibrium is corrected in the current period as an adjustable speed of $4 \%$. 
Therefore, in the short-run, the road vehicle exports are adjusted by $4 \%$ of the previous year's deviation from equilibrium. In addition, the coefficient of ECT of real exchange rate has a positive sign, while the coefficient of ECT of FDI, GDP per capita and trade openness has a negative sign.

\section{Granger Causality Test}

After the variable in the road vehicle export model are cointegrated, the Granger Causality can be performed to determine the causality relationships among the variables. Then, pairwise Granger Causality will be employed. The results of pairwise granger causality are as follows:

Table 5. Granger Causality Test

\begin{tabular}{|c|c|c|c|}
\hline Null Hypothesis & & F-Statistic & Prob. \\
\hline $\operatorname{lnFDI}$ & does not Granger Cause $\operatorname{lnEXROAD}$ & 0.43018 & 0.5162 \\
\hline $\operatorname{lnEXROAD}$ & does not Granger Cause lnFDI & 15.2261 & $0.0004 * * *$ \\
\hline $\ln P E R C$ & does not Granger Cause lnEXROAD & 1.27998 & 0.2656 \\
\hline $\operatorname{lnEXROAD}$ & does not Granger Cause lnPERC & 2.81994 & 0.1020 \\
\hline $\ln R E X$ & does not Granger Cause lnEXROAD & 6.04058 & $0.0191 * *$ \\
\hline $\operatorname{lnEXCAR}$ & does not Granger Cause lnREX & 0.16012 & 0.6915 \\
\hline OPN & does not Granger Cause lnEXROAD & 0.52188 & 0.4748 \\
\hline $\operatorname{lnEXROAD}$ & does not Granger Cause OPN & 5.12818 & $0.0298 * *$ \\
\hline $\ln P E R C$ & does not Granger Cause lnFDI & 6.63269 & $0.0144 * *$ \\
\hline $\operatorname{lnFDI}$ & does not Granger Cause lnPERC & 0.15378 & 0.6973 \\
\hline $\operatorname{lnREX}$ & does not Granger Cause lnFDI & 1.48829 & 0.2306 \\
\hline $\operatorname{lnFDI}$ & does not Granger Cause lnREX & 0.00078 & 0.9779 \\
\hline OPN & does not Granger Cause lnFDI & 10.5482 & $0.0026^{* * *}$ \\
\hline $\operatorname{lnFDI}$ & does not Granger Cause OPN & 4.08503 & $0.0510 *$ \\
\hline $\operatorname{lnREX}$ & does not Granger Cause lnPERC & 2.28372 & 0.1397 \\
\hline $\ln$ PERC & does not Granger Cause lnREX & 0.11764 & 0.7337 \\
\hline OPN & does not Granger Cause lnPERC & 0.79010 & 0.3801 \\
\hline $\operatorname{lnPERC}$ & does not Granger Cause OPN & 0.38248 & 0.5403 \\
\hline OPN & does not Granger Cause lnREX & 0.04831 & 0.8273 \\
\hline $\ln R E X$ & does not Granger Cause OPN & 2.91596 & $0.0966^{*}$ \\
\hline
\end{tabular}

Note. $* * *$ significance level at $.01, * *$ significance level at $.05, * *$ significance level at .10

In the long run, there are unidirectional causality relationship running from $\operatorname{lnEXROAD}$, to lnFDI and OPN, it suggests that road vehicle export granger cause FDI and trade openness. In the short-run, there are unidirectional causality relationship from $\ln R E X$ to $\operatorname{lnEXROAD}$, it means that $\ln R E X$ granger cause $\operatorname{lnEXROAD}$. Moreover, there are unidirectional causality relationship running from $\ln P E R C$ to $\ln$ FDI, and from $\ln R E X$ to OPN. There are bidirectional short- 
run causality relationships between OPN and lnFDI, it implies that trade openness granger cause FDI while FDI granger cause trade openness.

\subsection{The Impulse Response Function (IRF) Test Results}

The IRF is used to verify the response of $\operatorname{lnEXROAD}$ to shocks on $\operatorname{lnFDI}$, lnPERC, lnREX, and OPN. The IRF test in this research based on the generalized impulse. The results of IRF test on the road vehicle export model $(\operatorname{lnEXROAD})$ are displayed in Figure 2.

Response of $\ln E X R O A D$ to $\ln F D I$

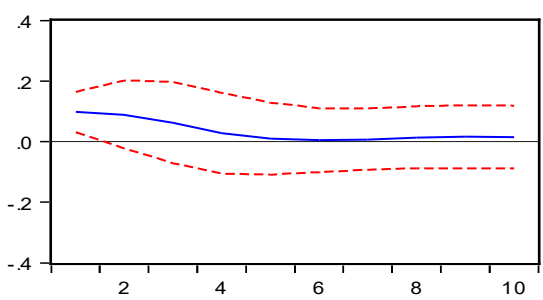

Response of $\operatorname{lnEXROAD}$ to $\ln R E X$

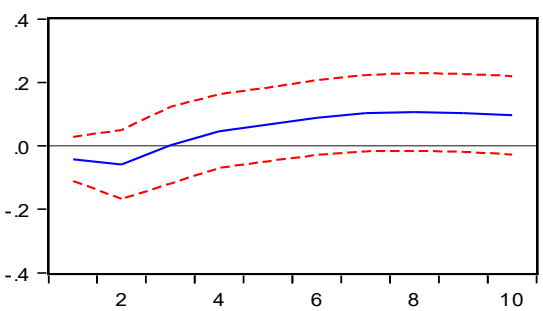

Response of $\operatorname{lnEXROAD}$ to $\ln P E R C$

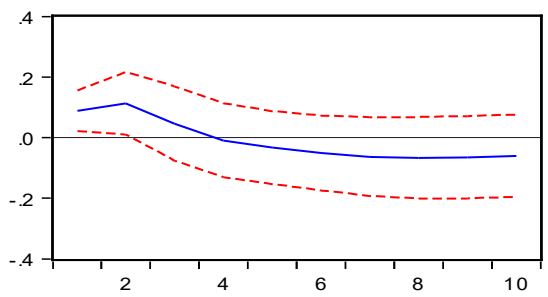

Response of $\ln E X R O A D$ to $\ln O P N$

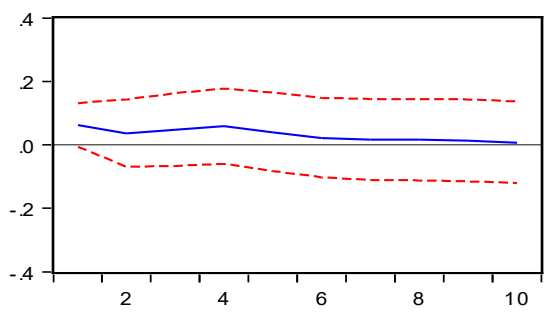

Figure 2. Impulse Response Functions (IRF) Test Results

From figure 2, the IRF reveals the result of the shock from lnEXROAD on $\operatorname{lnFDI}$, and $\operatorname{lnEXROAD}$ reveals a positive response in the first three years. For the shock to lnREX, lnEXROAD had a negative response in the first two years but responded positively from the third year onwards. The shock to OPN, lnEXROAD, shows a positive response in the following years. Lastly, the shock 
to $\ln$ PERC, $\operatorname{lnEXROAD}$ indicates a positive response for the first three years, but it then becomes a negative response since the fourth year onwards.

To clarify the IRF results, when there was a shock to FDI, GDP per capita, and trade openness, road vehicle exports positively responded in the following years, but when there was a shock to the real exchange rate, road vehicle exports negatively responded in the following year and shifted to a positive response from the third year.

\subsection{The Variance Decomposition (VD) Test}

The VD is conducted to evaluate whether the shock of InEXROAD can be explained by $\operatorname{lnFDI}, \ln$ PERC, $\operatorname{lnREX}$, and OPN in the same model for 10-year forecasting. The VD test results of lnEXROAD are presented in Table 6.

Table 6. Variance Decomposition Test

\begin{tabular}{ccccccc}
\hline Period & S.E. & $\operatorname{lnEXROAD}$ & $\operatorname{lnFDI}$ & $\ln$ PERC & $\operatorname{lnREX}$ & OPN \\
\hline \hline 1 & 0.214233 & 100.0000 & 0.000000 & 0.000000 & 0.000000 & 0.000000 \\
2 & 0.317495 & 98.61265 & 0.338102 & 0.338665 & 0.136608 & 0.573977 \\
3 & 0.361236 & 97.16262 & 0.415181 & 0.732907 & 1.208665 & 0.480631 \\
4 & 0.383141 & 92.71417 & 0.604860 & 2.689973 & 2.648529 & 1.342471 \\
5 & 0.400086 & 87.46952 & 0.840786 & 5.198322 & 4.811756 & 1.679616 \\
6 & 0.420078 & 81.01942 & 1.065415 & 8.524543 & 7.844000 & 1.546619 \\
7 & 0.443169 & 74.31668 & 1.156691 & 12.27156 & 10.85675 & 1.398317 \\
8 & 0.465450 & 68.65525 & 1.116078 & 15.58277 & 13.36245 & 1.283443 \\
9 & 0.484875 & 64.19339 & 1.042617 & 18.07458 & 15.49623 & 1.193179 \\
10 & 0.501442 & 60.66146 & 0.982018 & 19.75506 & 17.47158 & 1.129880 \\
\hline
\end{tabular}

The results in the first-year forecast indicate that 100 percent of the forecast error variance of $\operatorname{lnEXROAD}$ is from its own shock. Nevertheless, at the tenyear forecast horizon, its own shock declines to 61 percent of the forecast error variance. However, $\operatorname{lnFDI}$, lnPERC, $\operatorname{lnREX}$, and OPN shocks describe 1, 20, 17 and 1 percent, respectively of the forecast error variance of $\operatorname{lnEXROAD}$. Which implies that the variation in road vehicle exports is due to its own shock more than the other variables for tenth-year forecasting. However, the VD test results reveal that GDP per capita show a big impact on road vehicle exports, followed by the real exchange rate, trade openness, and FDI, respectively. 


\section{Conclusion}

This study aims to investigate the determinants of road vehicle exports with road vehicle exports as the dependent variables and the independent variables are FDI, real exchange rate, trade openness, and GDP per capita. The unit root, Johansen cointegration, impulse response functions and variance decomposition tests were employed. The results from the ADF unit root test revealed that all variables were stationary at the first difference level. The findings from the cointegration test revealed that all four factors; FDI, GDP per capita, real exchange rate, and trade openness were positively related to road vehicle exports. The IRF test confirmed that when there was a shock to FDI, GDP per capita, and trade openness, road vehicle exports positively responded in the earlier years, while the real exchange rate responded after three years. The results from a variance decomposition analysis confirmed that the shocks to GDP per capita, real exchange rate, trade openness, and foreign direct investment were $19.75,17.47,1.13$, and 0.98 percent, respectively and explained the error variance of exports for ten- year forecasting. Empirical results revealed that the growth rate of GDP per capita can expand production capacity and help expedite exports. The depreciation of the Thai baht attracts more foreign investment and increases the demand for Thai products. The growth in trade openness and foreign direct investment is also linked to the increase in the export volume of this sector. Therefore, the government needs to identify and develop new markets and encourage foreign investment by offering incentives. In summary, all four factors were found to affect Thailand's road vehicle exports, but in this study gross domestic product per capita and the real exchange rate played the most important role in increasing road vehicle exports.

\section{References}

[1] Bhatt, P. China's exports and foreign direct investment. AEID. 2013; 13(2): 183-196.

[2] Enimola, S. S. Foreign direct investment and export growth in Nigeria. JEIF. 2011; 3(11): 586.

[3] Epaphra, M. Determinants of export performance in Tanzania. JEL. 2016; 3(3): 470.

[4] Jongwanich, J. Determinants of export performance in East and Southeast Asia. The World Economy. 2010; 33(1): 20-41.

[5] Hoque, M., Yusop, Z. Impacts of Trade Liberalization on Export Performance in Bangladesh: An Empirical Investigation. SAEJ. 2012; 13 (2); 207-239.

[6] Kumari, D., Malhotra, N. Export-led growth in India: Cointegration and causality analysis. JEDS. 2014; 2(2): 297-310. 
[7] Liu, X., Shu, C. Determinants of export performance: evidence from Chinese industries. Econ Plann. 2003; 36(1): 45-67.

[8] Majeed, M. T., Ahmad, E., Khawaja, M. I. Determinants of exports in developing countries [with Comments]. PDR. 2006; 45(4): 1265-1276.

[9] Ministry of commerce. Thailand's foreign trade by country. [Internet]. [cited 2020 June 25]. Available from: http://www2.ops3.moc.go.th/

[10] Mohsen, A. S. Effects of trade openness, exchange rate, and oil price on the exports in Syria. EJES. 2015; 12(2): 76-83.

[11] Mohsen, A. S., Chua, S. Y., Sab, C. N. C. Trade liberalization, exports and imports in Syria. Foreign Trade Review. 2017; 52(2): 106-117.

[12] Selimi, D.N., Reçi, M.K., Sadiku, D.L. The Impact of Foreign Direct Investment on the Export Performance: Empirical Evidence for Western Balkan Countries. ILIRIA International Review. 2016; 6: 57-66.

[13] UN Comtrade. UN comtrade database. [Internet]. [cited 2019 February 10]. Available from: http://comtrade. un.org/data/

[14] Vural, İ. Y., Zortuk, M. Foreign direct investment as a determining factor in Turkey's export performance. EJBE. 2011; 4(7): 13-23.

[15] Wanna Yongpisanphop. Thailand industry outlook 2020-22: Automobile industry. [Internet]. Bangkok: Krungsri Research, Bank of Ayudhya Public Company limited. 2020. [cited 2020 July 1]. Available from: https://www.krungsri.com/bank/getmedia/6e 5cffe75a92-41e0-9a6f-e9e2b748b872/IO_Automobile_190805_EN_EX.aspx

[16] Zhang, Kevin Honglin. FDI and Host Countries' Exports: The Case of China. Economia Internazionale / International Economics. 2006; 59(1): 113-127. 